\title{
Efektivitas NataKelas Selama Pandemi Covid-19 Sebagai Media Pembelajaran Daring
}

\author{
Aryo Tunjung Kusumo ${ }^{1}$
}

\begin{abstract}
The COVID-19 pandemic has disrupted the conventional learning process. So a solution is needed to answer this problem. Online learning is one alternative that can overcome this problem. The purpose of the study was to obtain an overview of the implementation of online learning as an effort to suppress the spread of covid-19 in schools using the NataClass application. The results showed that teachers and students used the NataKelas application as a learning medium during the pandemic on a regular basis according to the face-to-face learning schedule, but the supervision of learning from parents was still lacking even though it had been prepared in the NataKelas application.
\end{abstract}

Intisari- Pandemi covid-19 telah mengganggu proses pembelajaran secara konvensional. Maka diperlukan solusi untuk menjawab permasalahan tersebut. Pembelajaran secara daring adalah salah satu pilihan alternatif untuk mengatasi masalah tersebut. Tujuan penelitian adalah untuk mendapatkan gambaran pelaksanaan pembelajaran daring sebagai salah satu upaya untuk menekan penyebaran covid-19 di Sekolah dengan menggunakan aplikasi NataKelas. Hasil dari penelitian ini menunjukkan bahwa guru dan murid menggunakan aplikasi NataKelas sebagai media pembelajaran selama masa pandemi secara rutin sesuai dengan jadwal pembelajaran tatap muka, namun pengawasan pembelajaran dari orangtua masih kurang walaupun sudah di siapkan di aplikasi NataKelas.

Kata Kunci- Covid-19, Pembelajaran Daring, Media Pembelajaran, NataKelas.

\section{PENDAHULUAN}

Wabah Covid-19 yang telah melanda 215 negara di dunia, memberikan tantangan tersendiri bagi lembaga pendidikan dari tingkat Paud, SD, SMP, SMA bahkan Perguruan Tinggi. Untuk memerangi Covid-19 Pemerintah telah membuat aturan larangan untuk berkerumun, menjaga jarak fisik (physical distancing) dan pembatasan sosial (social distancing), memakai masker dan selalu mencuci tangan. Melalui Kementerian Pendidikan dan Kebudayaan Pemerintah telah memberi larangan kepada seluruh lembaga pendidikan untuk melaksanakan pembelajaran konvensional atau tatap muka dan memerintahkan seluruh Lembaga Pendidikan untuk melaksanakan pembelajaran secara daring (Surat Edaran Kemendikbud Dikti No. 1 tahun 2020).

Pemanfaatan teknologi informasi menjadi solusi yang selaras dengan kebijakan pemerintah di masa pandemi ini dimana orang-orang tidak boleh berkerumun dan mengurangi kegiatan-kegiatan di luar rumah, sehingga konsumen mulai beralih lebih banyak melaksanakan aktivitas secara online. Pembelajaran secara daring memiliki tantangan, kekuatan dan hambatan tersendiri.[5]

${ }^{1}$ Jurusan Sistem Informasi, Universitas Bina Sarana Informatika, Jln. Kramat Raya No. 25 Jakarta Pusat 10420 INDONESIA (telp: 021-31908575; fax: 021-31908565; e-mail: aryo.atk@bsi.ac.id
Berdasarkan latar belakang masalah tersebut maka penulis melakukan penelitian tentang efektivitas penggunaan aplikasi NataKelas selama pandemi covid-19 sebagai media pembelajaran daring. Penelitian mencakup kualitas penggunaan aplikasi di lingkungan Sekolah, dengan melihat banyaknya aktivitas kegiatan pembelajaran yang dilakukan oleh Guru serta murid dengan pengawasan dari Pihak Sekolah dan Orang Tua/Wali Murid.

NataKelas merupakan aplikasi yang menjadi wadah/media untuk para guru dan murid melakukan pembelajaran. Dimana guru dapat memberikan materi dalam bentuk dokumen, foto ataupun video sebagai materi belajar untuk murid, selain itu guru bisa menggunakan NataKelas untuk memberikan tugas, ulangan serta memberikan nilai secara langsung.

Melalui aplikasi NataKelas juga, murid bisa mendapatkan materi, mengerjakan tugas/ulangan serta melihat hasil nilai yang diberikan oleh guru. Pihak Sekolah seperti Kepala Sekolah pun dapat memantau bagaimana aktivitas belajar antara guru dan murid. Orang Tua/Wali Murid juga dapat memantau nilai serta bagaimana pembelajaran anaknya secara langsung melalui aplikasi tersebut.

\section{TINJAUAN PUSTAKA}

Teknologi sangat penting dalam pendidikan, sehingga dapat menjadi fasilitator utama untuk meratakan pendidikan di Nusantara karena teknologi dapat dijadikan kemampuan belajar jarak jauh yang tidak lepas dari ruang, jarak dan waktu [14].

Pembelajaran daring adalah sistem pembelajaran yang dilakukan menggunakan platform-platform yang dapat membantu proses belajar mengajar secara jarak jauh sehingga tidak bertatap muka secara langsung. Tujuan dari adanya pembelajaran daring ialah selain mengurangi intensitas pertemuan secara langsung karena pandemi covid-19, pembelajaran secara daring dapat memberikan layanan pembelajaran yang bermutu dalam jaringan yang luas, masif dan terbuka untuk menjangkau peminat ruang belajar agar lebih banyak dan lebih luas.[13]

Pembelajaran secara daring mengajarkan peserta didik menjadi lebih mandiri, karena lebih menekankan pada student centered. Mereka menjadi lebih berani untuk mengemukakan ide dan pendapatnya. Serta pemerintah juga sudah menyediakan beberapa platform yang direkomnedasikan untuk dapat digunakan peserta didik selama pembelajaran daring.[10]

Berdasarkan penelitian, berbagai macam media belajar digunakan misalnya untuk video pembelajaran menggunakan youtube, untuk komunikasi, pertemuan dan berbagi data menggunakan google classroom, google meet, zoom cloud meeting, whatsapp dan lain-lain. Berdasarkan hasil penelitian dapat disimpulkan bahwa penggunaan media belajar maupun 
platform-platform online yang lain bisa menjadi solusi alternatif dalam pembelajaran secara daring, demi kelangsungan pembelajaran pada setiap satuan Pendidikan. [1]

Pembelajaran secara daring dalam beberapa tahun terakhir telah menjadi tuntutan dunia pendidikan. Bahkan di era revolusi industri 4.0 pembelajaran secara daring dibutuhkan dalam pembelajaran. [11]

Berbagai media yang ada saat ini dapat digunakan untuk mendukung berlangsungnya pembelajaran secara daring. Misalnya kelas-kelas virtual menggunakan Edmodo, Schoology dan Google Classroom.[12]

Ada beberapa aplikasi juga yang dapat digunakan untuk membantu proses belajar mengajar, misalnya whatsapp, zoom, web blog, edmodo dan lain-lain. Selama masa pendemi covid19 pemerintah juga berperan dalam menangani ketimpangan kegiatan belajar. Ada 12 platform yang bisa diakses oleh peserta didik untuk belajar dari rumah dilansir dari laman resmi Kemendikbud RI yaitu (1) Rumah belajar; (2) Meja kita; (3) Icando; (4) Indonesiax; (5) Google for education; (6) Kelas pintar; (7) Microsoft office 365; (8) Quipper school (9) Ruang guru; (10) Sekolahmu; (11) Zenius; (12) Cisco webex.

Pembelajaran secara daring dapat membuat peserta didik belajar secara mandiri dan diharapkan motivasinya dapat meningkat. Namun, ada kelemahan dari pembelajaran secara daring dimana peserta didik tidak terawasi dengan baik selama pelaksanaan pembelajaran daring. [2]

Tantangan dari adanya pembelajaran secara daring adalah penguasaan dan keahlian dalam penggunanaan teknologi dari pihak pendidik maupun peserta didik. [4] Ciri-ciri peserta didik dalam kegiatan belajar secara daring atau secara online yaitu :

1. Semangat belajar: semangat peserta didik ketika proses pembelajaran kuat atau tinggi untuk pembelajaran mandiri. Saat pembelajaran secara daring kriteria ketuntasan pemahaman materi pada pembelajaran dipengaruhi oleh peserta didik itu sendiri. Pengetahuan akan ditemukan sendiri serta peserta didik harus mandiri. Sehingga kemandirian belajar tiap peserta didik menjadikan perbedaan dalam keberhasilan belajar.

2. Literacy terhadap teknologi : berikutnya selain kemandirian terhadap kegiatan belajar adalah tingkat pemahaman peserta didik terhadap pemakaian teknologi disaat pembelajaran secara daring merupakan salah satu keberhasilan dari pelaksanaan pembelajaran daring. Penguasaan teknologi yang digunakan dalam pembelajaran daring harus sudah dipersiapkan sebelumnya. Peralatan yang secara umum digunakan sebagai sarana pembelajaran daring ialah komputer smartphone, maupun laptop. Perkembangan teknologi di era digital ini menciptakan berbagai macam aplikasi atau fiturfitur yang dapat digunakan sebagai sarana untuk mendukung pembelajaran secara daring.
3. Kemampuan berkomunikasi interpersonal : di bagian ini kemampuan berkomunikasi dan kemampuan interpersonal merupakan kemampuan yang harus dikuasai sebagai salah satu syarat untuk keberhasilan dalam pembelajaran daring. Untuk menjalin hubungan serta interaksi antar peserta didik maka peserta didik membutuhkan kemampuan interpersonal. Meskipun pembelajaran online dilaksanakan secara mandiri sebagai makhluk sosial peserta didik tetap membutuhkan interaksi dengan orang lain. Maka dari itu kedua kemampuan tersebut harus tetap dilatih oleh peserta didik dan dapat digunakan dalam kehidupan bermasyarakat.

4. Berkolaborasi : Peserta didik harus mampu berinteraksi antar peserta didik lainnya ataupun dengan guru dalam sebuah forum yang telah disediakan, karena dalam pembelajaran secara daring yang melaksanakan adalah peserta didik itu sendiri. Sehingga ketika peserta didik sedang mengalami kesulitan dalam memahami materi interaksi ini dapat digunakan. Selain hal tersebut, interaksi ini juga berguna untuk melatih jiwa sosial mereka. Supaya jiwa anti sosial dan individualisme tidak terbentuk didalam diri peserta didik. Dalam proses pembelajaran secara daring juga peserta didik mampu memahami pembelajaran dengan kolaborasi. Peserta didik akan dilatih dan belajar agar mampu berkolaborasi baik dengan lingkungan sekitar atau dengan bermacam sistem yang mendukung pembelajaran daring.

5. Keterampilan untuk belajar mandiri: kemampuan dalam belajar mandiri merupakan karakteristik pembelajaran secara daring dan sangat diperlukan dalam pembelajaran daring. Karena dalam prosesnya peserta didik akan mencari, menemukan sampai dengan menyimpulkan sendiri yang telah dipelajari.

Pembelajaran mandiri adalah proses dimana peserta didik dilibatkan langsung dalam identifikasi apa yang perlu untuk dipelajari dan menjadi pemegang kendali dalam proses pembelajaran[4]. Ketika peserta didik belajar secara mandiri, dibutuhkan motivasi dari peserta didik sebagai penunjang keberhasilan dalam proses pembelajaran secara daring.

Pada penelitian terdahulu yang membahas mengenai analisis pelaksanaan aktivitas belajar secara daring terhadap peserta didik pada masa tanggap darurat covid 19, maka dengan melihat fenomena ini peneliti ingin melakukan penelitian dengan tujuan untuk mengidentifikasi pelaksanaan pembelajaran daring selama adanya kebijakan study from home selama pandemi covid 19.[4]

Pembelajaran secara daring bahkan dapat dilakukan melalui media sosial seperti Facebook dan Instagram [6].

\section{METODE PENELITIAN}

Jenis penelitian yang digunakan adalah penelitian kualitatif. Tujuan penelitian ini adalah menggambarkan pembelajaran daring yang diselenggarakan di tingkat Sekolah Dasar (SD), Sekolah Menengah Pertama (SMP) \& Sekolah Menengah Atas (SMA). Pembelajaran daring yang dimaksud dalam 
penelitian ini adalah pembelajaran menggunakan media yang diakses menggunakan layanan internet dari service provider. Penelitian ini dilakukan dengan melihat activity logs yang merupakan catatan yang merekam segala kejadian-kejadian yang berlangsung pada suatu aplikasi dijalankan.

Analisis data penelitian dilakukan menggunakan model analisis Miles \& Huberman yang terdiri dari tiga tahapan, yaitu reduksi data, display data, serta penarikan dan verifikasi kesimpulan.[1]

Mengenai ketiga tahapan yang telah disebutkan secara lebih lengkapnya adalah sebagai berikut:

\section{Reduksi Data}

Reduksi data diartikan menjadi proses pemilihan, pemusatan perhatian pada penyederhanaan, pengabstrakan, dan transformasi data kasar yang muncul dari catatan-catatan yang tertulis. Reduksi data akan terus berlangsung selama proyek yang berorientasi penelitian kualitatif berlangsung. Antisipasi bahwa akan ada reduksi data sudah terlihat pada saat penelitiannya memutuskan kerangka konseptual wilayah penelitian, masalah penelitian, dan pendekatan pengumpulan data mana yang dipilihnya. Selama pengumpulan data berjalan, terjadilah tahapan reduksi berikutnya. Reduksi data/transformasi ini berjalan terus sesudah penelian lapangan, sampai laporan akhir tersusun lengkap.

Reduksi data adalah bagian dari analisis dan merupakan suatu bentuk analisis yang menajamkan, menggolongkan, mengarahkan, membuang yang tidak perlu, dan mengorganisasi data dengan cara sedemikian rupa hingga kesimpulan finalnya dapat ditarik serta diverifikasi.

Dengan reduksi data tersebut peneliti tidak perlu mengartikannya menjadi kuantifikasi. Data kualitatif dapat disederhanakan serta ditransformasikan dalam berbagai macam cara, yakni: melalui seleksi ketat, melalui ringkasan atau uraian singkat, menggolongkannya dalam satu pola yang lebih luas, dan sebagainya. Kadangkala bisa juga mengubah data ke dalam angka-angka atau peringkat-peringkat, namun tindakan ini tidak selalu bijaksana.

\section{Penyajian Data}

Suatu penyajian menjadi sekumpulan informasi tersusun yang memberi kemungkinan akan adanya penarikan kesimpulan lalu pengambilan tindakan. Meyakini bahwa dengan penyajian-penyajian yang lebih baik merupakan suatu cara yang utama bagi analisis kualitatif yang valid, yang meliputi: berbagai jenis matrik, grafik, jaringan serta bagan. Semuanya dirancang agar menggabungkan informasi yang tersusun dalam suatu bentuk yang padu serta mudah diraih.

Dengan demikian penganalisis dapat melihat apa yang sedang terjadi, serta menentukan apakah menarik kesimpulan yang benar atau akan terus melanjutkan melakukan analisis yang menurut saran yang dikisahkan sebagai sesuatu yang mungkin berguna.

\section{Menarik Kesimpulan}

Penarikan kesimpulan hanya sebagian dari kegiatan dari konfigurasi yang utuh. Kesimpulan-kesimpulan yang didapatkan juga akan diverifikasi selama penelitian masih berlangsung. Verifikasi itu mungkin hanya pemikiran singkat yang kembali melintas dalam pikiran penganalisis (peneliti) selama proses menulis, suatu tinjauan ulang atau koreksi pada catatan-catatan lapangan, atau mungkin menjadi lebih seksama dan dapat menghabiskan tenaga dengan peninjauan kembali serta tukar pikiran di antara peneliti untuk mengembangkan temuan yang didapatkan dengan kesepakatan intersubjektif atau juga upaya-upaya yang luas untuk menempatkan salinan suatu temuan dalam seperangkat data yang lain. Singkatnya, informasiinformasi yang muncul dari data yang lain harus diuji kebenarannya, kekokohannya, dan kecocokannya, yang juga merupakan validitasnya. Kesimpulan akhir tidak hanya terjadi pada saat proses pengumpulan informasi dan data saja, akan tetapi perlu ada verifikasi agar benar-benar dapat dipertanggungjawabkan. Secara skema proses analisis data menggunakan model analisis data interaktif dapat dilihat pada bagan berikut:

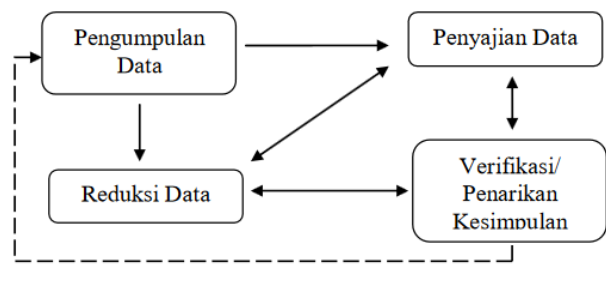

Sumber: [1]

Gbr. 1 Model Analisis Data Interaktif

\section{HASIL DAN PEMBAHASAN}

Activity logs merupakan cara menganalisa penuli untuk mendapatkan hasil apakah aplikasi NataKelas digunakan secara efektif oleh guru, peserta didik serta orang tua/wali peserta didik.

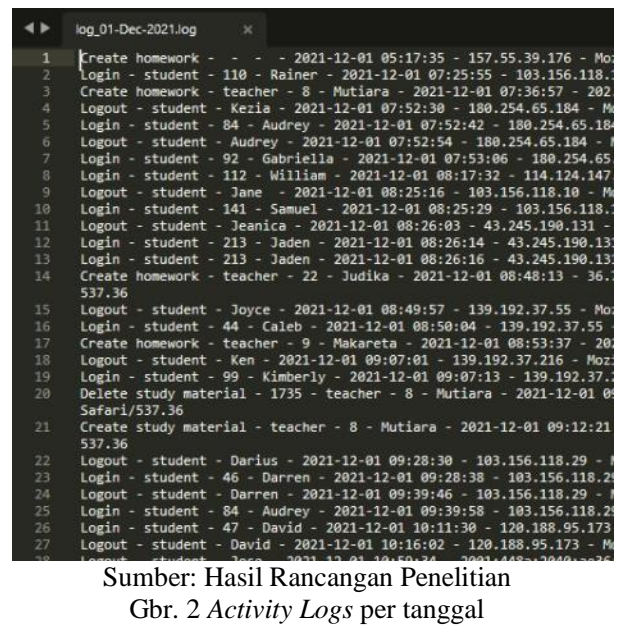


Dari Acitvity logs terlihat adanya efektifas penggunaan aplikasi cukup baik oleh guru maupun peserta didik, dengan terekamnya aktivitas pemberian tugas maupun materi oleh guru, dan peserta didik mengumpulkan tugas sesuai dengan arahan dari guru. Dalam Activity logs di setiap harinya ratarata ada 150-400 aktifitas yang tercatat, hal ini membuktikan bahwa aplikasi ini sangat efektif dalam pembelajaran daring bagi guru \& murid.

Secara keseluruhan, guru \& peserta didik puas dengan pembelajaran yang fleksibel. Dengan pembelajaran daring, murid tidak terkendala waktu dan tempat dimana mereka dapat mengikuti pembelajaran dari rumah masing-masing maupun dari tempat dimana saja. Dengan pembelajaran secara daring, guru memberikan materi pembelajaran melalui kelaskelas virtual yang telah disiapkan serta dapat diakses dimana pun dan kapan pun tidak terikat ruang dan waktu. Ketiadaaan hambatan fisik serta batasan ruang serta waktu menyebabkan peserta didik lebih nyaman untuk saling berkomunikasi [8]. Kemudian dengan pembelajaran secara daring juga menghilangkan rasa canggung peserta didik yang membuat mereka menjadi lebih berani berekpresi dalam bertanya serta mengutarakan ide secara bebas. Pembelajaran secara daring juga memiliki kelebihan bagi peserta didik agar mampu menumbuhkan kemandirian belajar (self regulated learning).

Penggunaan aplikasi mampu meningkatkan siswa untuk mandiri dalam belajar [9]. Pembelajaran secara daring lebih bersifat berpusat pada peserta didik yang membuat mereka mampu memunculkan rasa tanggung jawab dan otonomi dalam belajar (learning autuonomy). Sayangnya Orang tua/Wali peserta didik jarang terekam dalam activity logs, ada kemungkinan Orang tua/Wali peserta didik terbiasa dengan melihat hasil/nilai pembelajaran anaknya di akhir semester dengan adanya Raport Pembelajaran. Sehingga Aplikasi NataKelas sangat kurang efektif bagi Orang tua/Wali peserta didik. Karena hal ini pula, untuk meningkatkan efektifitas aplikasi NataKelas perlu dikembangkan dengan membuat tambahan fitur Laporan Hasil Nilai Pembelajaran di setiap bulan dan Raport Hasil Pembelajaran di setiap akhir semester, agar penggunaan aplikasi NataKelas untuk Orang tua/Wali peserta didik bisa efektif.

\section{KESIMPULAN}

Dengan melihat aktivitas log pada aplikasi NataKelas, maka dapat disimpulkan bahwa :

1. NataKelas diakses oleh peserta didik, guru sebagai sarana dan prasarana untuk melaksanakan pembelajaran secara daring. Pembelajaran daring sangat efektif untuk mengatasi proses pembelajaran yang dapat memungkinan guru serta peserta didik berinteraksi dalam kelas virtual yang dapat diakses dimana saja.

2. NataKelas dapat digunakan sebagai media pembelajaran daring yang bisa dijadwalkan seperti pembelajaran tatap muka biasanya.
3. Guru memanfaatkan NataKelas sebagai media/wadah untuk bisa memberikan materi, tugas, ulangan bahkan laporan sikap muridnya ke orang tua/wali murid melalui aplikasi ini.

4. Murid juga memanfaatkan aplikasi NataKelas untuk mengerjakan tugas, ulangan atau membaca materi-materi yang sudah guru berikan. Hal ini sangat efektif tanpa mengurangi esensi dari pembelajaran tatap muka.

5. Sayangnya Orang tua/Wali murid jarang terekam dalam activity logs, ada kemungkinan Orang tua/Wali Murid terbiasa dengan melihat hasil/nilai pembelajaran anaknya di akhir semester dengan adanya Raport Pembelajaran. Sehingga Aplikasi NataKelas sangat kurang efektif bagi Orang tua/Wali Murid. Karena hal ini pula, untuk meningkatkan efektifitas aplikasi NataKelas perlu dikembangkan dengan membuat tambahan fitur Laporan Hasil Nilai Pembelajaran di setiap bulan dan Raport Hasil Pembelajaran di setiap akhir semester, agar penggunaan aplikasi NataKelas untuk Orang tua/Wali Murid bisa efektif.

\section{REFERENSI}

[1] Alami, Y., "Media Pembelajaran Daring pada Masa Covid-19", Tarbiyatu Wa Ta'lim: Jurnal Pendidikan Agama Islam 2(1) hal. 49-56 https://ejournal.staisyamsululum.ac.id/index.php/jtt/article/view/71, 2020

[2] Ali Sadikin, \& Afreni Hamidah, "Pembelajaran Daring di Tengah Wabah Covid-19 (Online Learning in the Middle of the Covid-19 Pandemic)", BIODIK: Jurnal Ilmiah Pendidikan Biologi Volume 6 Nomor 02 Hal. 214-224, 2020

[3] Aureza,Ramadhana \& Ardin, "Pengaruh Media Daring Terhadap Kepuasan Belajar Siswa Pada Masa Pandemi Covid 19 Di SMPN 35 Bekasi”, JURNAL PENDIDIKAN, p-ISSN 2715-095X, e-ISSN 26865041Volume 30, No.3, Nopember 2021 (377-386) Online: http://journal.univetbantara.ac.id/index.php/jp, 2021.

[4] Hasanah, dkk, "Analisis Aktivitas Belajar Daring Mahasiswa Pada Pandemi COVID-19. Jurnal Pembelajaran Daring Sebagai Upaya Study From Home (SFH).", Jurnal Pendidikan Administrasi Perkantoran (JPAP) Volume 8, Nomor 3, 2020 Volume 1 No.1, 2020.

[5] Jamaluddin, Ratnasih, Gunawan \& Paujiah, "Pembelajaran daring masa pandemik Covid-19 pada calon guru: hambatan, solusi dan proyeksi", 2020.

[6] Kumar, V., \& Nanda, P, "Social Media in Higher Education." International Journal of Information and Communication Technology Education (https://doi.org/10.4018/ijicte.2019010107), 2018.

[7] Latifah, Nur \& Asep Supena, "Analisis Attention Siswa Sekolah Dasar Dalam Pembelajaran Jarak Jauh di Masa Pandemi Covid-19", JURNAL BASICEDU Volume 5 Nomor 3Tahun 2021 hal 1175-1182, https://jbasic.org/index.php/basicedu/article/view/887, 2021.

[8] Nilayani , S. A. P., "Survei Kepuasan Siswa Terhadap Proses Belajar Daring Selama Pandemi Covid-19”, Cetta: Jurnal Ilmu Pendidikan 3(3) hal 453-462. http://jayapanguspress.penerbit.org/index.php/cetta/article/view/542, 2020

[9] Oknisih, N., \& Suyoto, S, "Penggunaan APLEN (Aplikasi Online) Sebagai Upaya Kemandirian Belajar Siswa”, In Seminar Nasional Pendidikan Dasar Vol. 1 No. 01, 2019.

[10] Oktafia Ika Handarini \& Siti Sri Wulandari, "Pembelajaran Daring Sebagai Upaya Study From Home (SFH) Selama Pandemi Covid 19.", Jurnal Pendidikan Administrasi Perkantoran (JPAP) Volume 8, Nomor 3,2020 . 
[11] Pangondian, R. A., Santosa, P. I., \& Nugroho, E., "Faktor-Faktor Yang Mempengaruhi Kesuksesan Pembelajaran Daring Dalam Revolusi Industri 4.0.", In Seminar Nasional Teknologi Komputer \& Sains (SAINTEKS) Vol.1 No.1, 2019

[12] Rahmanto, M. A., \& Bunyamin, B., "Efektivitas Media Pembelajaran Daring melalui Google Classroom", Jurnal Pendidikan Islam 11(2) hal. 119-135 https://doi.org/10.22236/jpi.v11i2.5974, 2020.

[13] Sofyana \& Abdul, "Pembelajaran Daring Kombinasi Berbasis Whatsapp Pada Kelas Karyawan Prodi Teknik Informatika Universitas PGRI Madiun.”, Jurnal Nasional Pendidikan Teknik Informatika. Volume 8 Nomor 1, Halm. 81-86, 2019.

[14] Vagg, T., Balta, J. Y., Bolger, A., \& Lone, M., "Multimedia in Education: What do the Students Think? Health Professions Education" 6(3) page 325-333, https://doi.org/10.1016/j.hpe.2020.04.011, 2020.

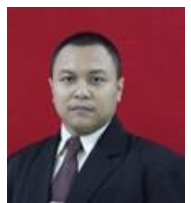

Aryo Tunjung Kusumo, M.Kom. Lahir di Surakarta pada tanggal 07 Maret 1986. Lulus dari Program Strata Satu (S1) Jurusan Sistem Informasi pada tahun 2009 dan Program Strata Dua (S2) bidang Ilmu Komputer konsentrasi EBussiness pada tahun 2015 di STMIK NUSA MANDIRI Saat ini bekerja sebagai Staff Pengajar di Universitas BSI serta Programmer di PT.Inti Nata Sintesis (INS). Penulis jurnal "Kualitas Layanan Website BSI Career Center dengan metode Webqual" \& "Rancang Bangun Sistem Informasi Penjualan Berbasis Web pada Smooth-Tee dengan Metode Waterfall" 